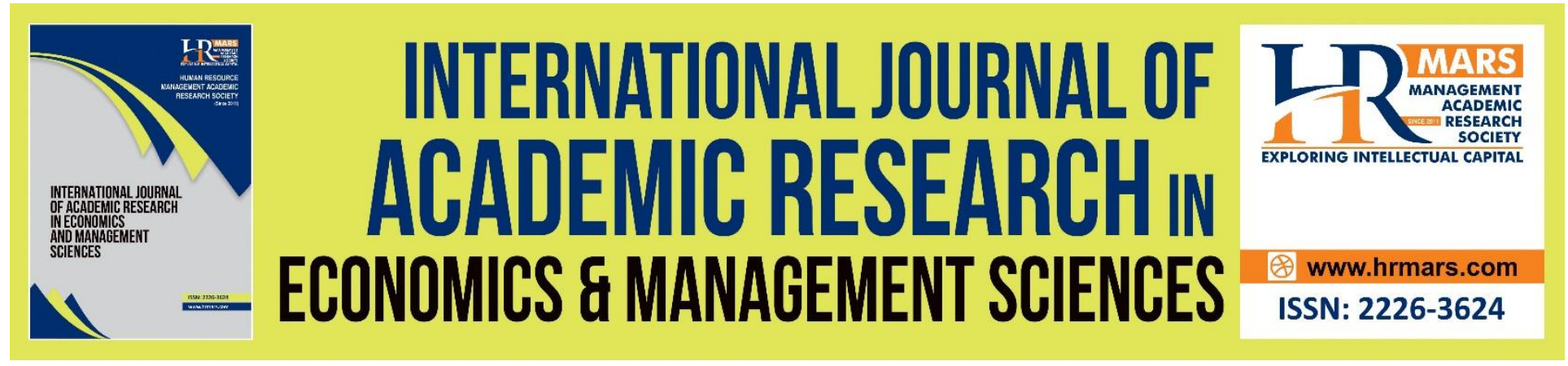

\title{
Impact of Opening Up of Border in Serudong, Malaysia on Output: Input-Output Table Analysis
}

Rafiq Idris

To Link this Article: http://dx.doi.org/10.6007/IJAREMS/v10-i4/11998

DOI:10.6007/IJAREMS/v10-i4/11998

Received: 19 October 2021, Revised: 22 November 2021, Accepted: 06 December 2021

Published Online: 28 December 2021

In-Text Citation: (Idris, 2021)

To Cite this Article: Idris, R. (2021). Impact of Opening Up of Border in Serudong, Malaysia on Output: InputOutput Table Analysis. International Journal of Academic Research in Economics and Management and Sciences, 10(4), 94-98.

Copyright: (C) 2021 The Author(s)

Published by Human Resource Management Academic Research Society (www.hrmars.com)

This article is published under the Creative Commons Attribution (CC BY 4.0) license. Anyone may reproduce, distribute, translate and create derivative works of this article (for both commercial and non-commercial purposes), subject to full attribution to the original publication and authors. The full terms of this license may be seen at: $\underline{\text { http://creativecommons.org/licences/by/4.0/legalcode }}$

Vol. 10, No. 4, 2021, Pg. 94 - 98

http://hrmars.com/index.php/pages/detail/IJAREMS

JOURNAL HOMEPAGE

Full Terms \& Conditions of access and use can be found at http://hrmars.com/index.php/pages/detail/publication-ethics 


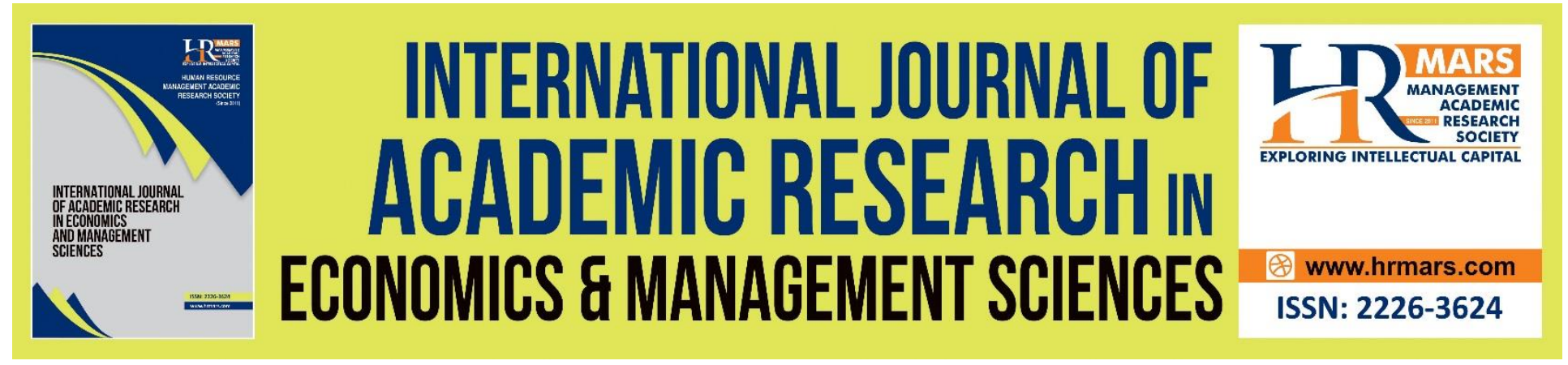

\title{
Impact of Opening Up of Border in Serudong, Malaysia on Output: Input-Output Table Analysis
}

\author{
Rafiq Idris \\ Senior Lecturer, Universiti Malaysia Sabah. \\ Author's Email: rafiq8idris@gmail.com
}

\begin{abstract}
The relocation of Indonesian capital city from Jakarta to East Kalimantan is expected to give big impact on economic development in Borneo island, specifically Kalimantan. The effects are even greater when the Malaysian government announced that there is a plan to have road connectivity with North Kalimantan. This has the potential to cause the demand for goods and services to rise, investment inflow to be substantial in amount, cross border trade to increase and infrastructure development to move faster among others. From Malaysia's perspective, many are optimistic that Sabah and Sarawak will have greater economic interaction with neighbouring provinces in Kalimantan. Bilateral trade will increase, tourists movement will be much bigger and the demand for services in certain strategic areas will go up such as in education and health sector. While many have given their views with regard to the costs and benefits of opening new border entry point, limited studies have attempted to estimate the impact of opening up border in terms of magnitude on output at least for Serudong. This study attempts to estimate the impact of increase in final demand of products on output in Sabah using the Input-Output Table Analysis.

Keywords: Border, Serudong, Input-Output Table, Output Multiplier, Sabah

\section{Introduction}

The relocation of Indonesian capital city from Jakarta to East Kalimantan is expected to give big impact on economic development in Borneo island, specifically Kalimantan. Many have given their views with regard to border opening, road construction to connect with North Kalimantan, new border township and Indonesia's capital city relocation. In general, many researchers and analysts have highlighted that the impact to be positive, at least from economic perspective. In terms of measurement, how much will it benefit Sabah? How much output will increase as a result of road construction in Serudong? How will an increase in final demand for food and accommodation sector affect the economy? How much output to be generated for the economy as a result of increase in final demand? This study estimates the impact of increase in final demand on the economy using Input-Output Table Analysis.
\end{abstract}




\section{Literature Review}

There are many studies across different countries that have been undertaken with regard to impact of opening up border entry point, cross border trade and Sabah-Kalimantan economy. This can be seen in the work of (Idris, 2018; Idris, 2019; Idris, Mansur and Marso, 2019; Idris and Mansur, 2018; Idris, 2018; Idris et al., 2018; Idris, 2017). However, most of the past studies did not attempt to estimate the impact of greater interaction on output that can be generated for Sabah's economy. This study shall suggest some numbers with regard to the impact on Sabah's economy based on several assumptions to be discussed in the next section.

\section{Methodology}

The impact of increase in final demand on the economy is being estimated using Input-Output Table Analysis. Regional Input-Output Table 2015 is being used for the analysis and as a guide. For this purpose, the output multiplier is being computed as discussed in (Miller and Blair, 2009).

In this study, it is assumed that the final demand for these 2 sectors increase individually and being combined. The scenarios for impact analysis are being divided into the following:

Scenario 1: increase in final demand for goods and services in food, beverages and accommodation sector amounting RM1 million a month, while other things remain unchanged.

Scenario 2: increase in final demand goods and services and in construction sector by RM600 million, while other things remain unchanged.

\section{Results}

Table 1 shows the results of Input-Output Table analysis. Assuming border is being opened in Serudong-Simanggaris, hence causing greater movement of people, goods and services between Sabah and North Kalimantan, causing the final demand for food, beverages and accommodation sector products to go up, it is estimated that the output in that sector to increase by RM12.514 million.

Besides, the input-output analysis indicates that RM12 million increase in final demand from food, beverages and accommodation sector, shall generate RM24.679 millions of output in the economy or an increase by $0.0278 \%$ of total output. 
Table 1: The input-output analysis: Impact of Increase in Final demand in Food, Beverages and Accommodation Sector (Scenario 1)

\begin{tabular}{|l|c|c|c|c|c|}
\hline \multicolumn{1}{|c|}{ ASSUMPTION: } & SECTOR & AMOUNT BY & $\begin{array}{c}\text { ESTIMATED TO } \\
\text { GENERATE RM X } \\
\text { OF OUTPUT IN } \\
\text { THE SECTOR }\end{array}$ & $\begin{array}{c}\text { ESTIMATED TO } \\
\text { GENERATEA TOTAL } \\
\text { EFFET OF RM XX OF } \\
\text { OUTPUTIN THE } \\
\text { ECONOMY }\end{array}$ & $\begin{array}{c}\text { \% CHANGE TO } \\
\text { OVERALL OUTPUT }\end{array}$ \\
\hline $\begin{array}{l}\text { INCREASE IN FINAL DEMAND } \\
\text { FOR PRODUCTS IN }\end{array}$ & $\begin{array}{l}\text { FOOD \& BEVERAGES AND } \\
\text { ACCOMODATION SECTOR }\end{array}$ & BYRM12,000,000 & $12,514,894.15$ & $24,679,817.97$ & 0.0278 \\
\hline
\end{tabular}

Table 2: The input-output analysis: Impact of Increase in Final demand in Construction Sector (Scenario 2)

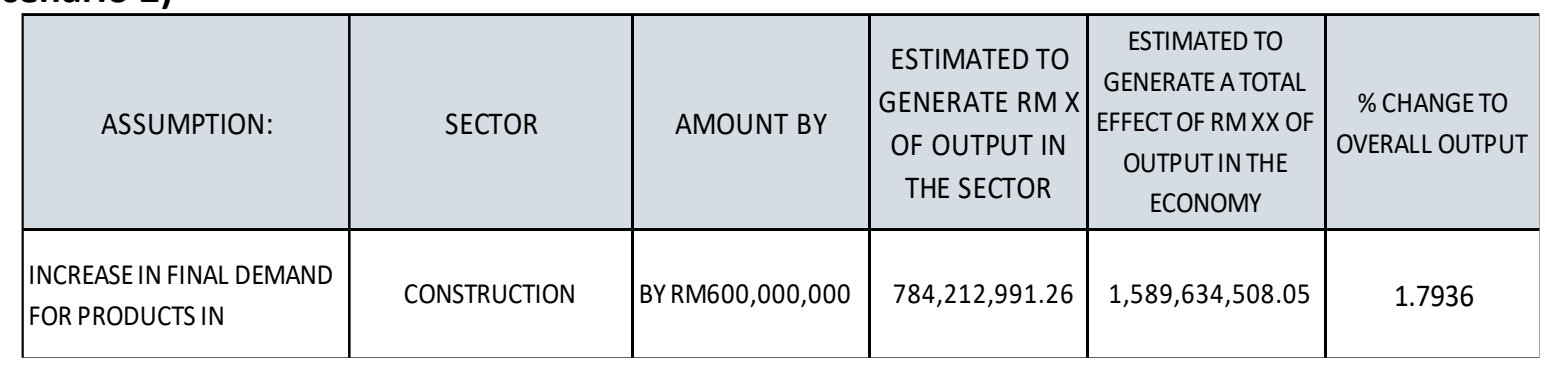

Table 2 shows the results of Input-Output Table analysis. Assuming road construction take place, causing the final demand for products and or services from construction sector to go up by RM600 million only and other things remain the same, it is estimated that RM1.59 billions of output will be generated in the economy.

Having said that, the real impact if materialize depends on many factors such as the dynamics of current economic situation, timing of real spending being made, policy on people and goods movement in border areas, the actual amount being spent by players in the economy and how far they are from the assumptions being made in this study.

While discussing the positive impact of opening up border entry point, it is also important to acknowledge that there will are also many issues to be associated with this development. Indeed, all aspects of the economy and other areas should not be overlooked.

\section{Conclusion}

The opening of border entry point in Serudong-Simanggaris is expected to benefit Sabah's economy. Based on a very conservative assumptions, an increase in final demand for food, beverages and accommodation sector by RM12 million a year, is expected to generate $0.027 \%$ output growth to the economy. In addition, assuming the road project in Serudong-Simanggaris is being implemented, the impact on economy would be a growth of $1.79 \%$ to output. On one end, the real future increase in final demand in the economy for sure will not be limited to these two sectors only. It is also imperative that more studies to be undertaken to examine the impact of opening up border entry point on other aspects as well such as on environment, security, social and culture among others. 
INTERNATIONAL JOURNAL OF ACADEMIC RESEARCH ECONOMICS AND MANAGEMENT SCIENCES

Vol. 10 , No. 4, 2020, E-ISSN: 2226-3624 ㄷ 2020 HRMARS

\section{Acknowledgement}

The study is part of a research on Sabah-Kalimantan economy funded by Universiti Malaysia Sabah's grant (SDK0120-2019)

\section{References}

Miller, R. E., \& Blair, P. D. (2009). Input-Output Analysis: Foundations and Extensions, 2nd Edition, New York: Cambridge University Press.

Idris, R. (2018). Potential Benefits of Sabah-Kalimantan Road Connectivity: the Effect of Common Border on Export. R. Idris and K. Mansur (ed). Collection of Studies on Sabah Kalimantan Economic Relations. Right Book Publications.

Idris, R. (2019). Relocation of Indonesian Capital City: Road Connectivity with Kalimantan Has the Potential to Make the Impact to be Significant for Sabah. Rafiq Idris, Kasim Mansur and Rizal Idris (ed). Studies on the Economy of Sabah and Kalimantan. IPB Press

Idris, R., Mansur, K., \& Marso. (2019). Economy of Kalimantan: a Snapshot. Rafiq Idris, Kasim Mansur and Rizal Idris (ed). Studies on the Economy of Sabah and Kalimantan. IPB Press

Idris, R., \& Mansur, K. (2018). Sabah-Kalimantan Road Connectivity: Potential Benefits. R Idris, K Mansur (ed). Collection of Studies on Sabah-Kalimantan Economic Relations. Right Book Publications.

Idris, R. Z., \& Idris. (2018). Malaysia-Indonesia Relations. R. Idris and K. Mansur (ed). Collection of Studies on Sabah-Kalimantan Economic Relations. Right Book Publications.

Idris, R., Majid, A., \& Hao, L. (2018). Malaysia's Consumer Products in North Kalimantan. R. Idris and K. Mansur (ed). Collection of Studies on Sabah-Kalimantan Economic Relations. Right Book Publications. 